\title{
ABILITY TO CONDUCT A CHORUS AS AN ELEMENT OF PROFESSIONAL COMPETENCE OF A TEACHER
}

The article is aimed at revealing a complex of properties of a music teacher which are necessary and sufficient for an effective management of pupils' choral singing. It has been determined that the will is the most important component of the aptitude to chorus conducting. A music teacher should be able to achieve synergy effect from interaction of all participants in the process of choral singing. Such a point of view provides opportunities for development of synergetic approach in the study of the phenomenon of music education.

Keywords: music teacher, chorus conducting, aptitude, will, synergy.

Problem statement. Choral singing has been an integral component of the mass educational process at all times, in all countries and in every sociocultural, political and economic environment. And today, the singing in teams remains the most natural, affordable, effective and attractive way of making music, as well as the main type of creative musical activity of both pupils and students.

Review of recent researches and publications. As a result, the choral management should be regarded as an essential component of the complex set of personal qualities that are called "professional competence" in the modern art pedagogy. The set of qualities that was mentioned before was thoroughly studied in the works of eminent conductors, many of whom were also teachers and chorus conductors (A. Avdievskiy, G. Dmitrievskiy, A. Yegorov, M. Kolessa, V. Krasnoschekov, A. Laschenko, A. Marchlevskiy, I. Musin, K. Olkhov, A. Pazovsky, K. Pigrov, O. Polyakov, K. Ptitsa, P. Chesnokov, etc.). A lot of attention was paid to the problem of the conductor's competence by the representatives of pedagogy and practice of teaching music in secondary school (the works of L. Biruykova, A. Kozyr, A. Kolomiets, L. Labintseva, T. Osadchaya, G. Padalka, L. Pankiv and L. Sbitneva, etc). Chinese experts have also made their own contribution to the tradition of problem research (Lin Hao, Ma Ge Shun, Sui Din Chrun, Cio Li, Chen and Xin, Yang Hung Nian and others).

At the same time, choral singing and its influence on the development of personality and the activity of the person who is managing this process is an endless integral phenomenon that causes the relentless attention of researchers, stimulating the seeking for new research approaches, methods and perspectives.

Our interest in choral singing at secondary school is determined by the new conditions of public musical system functioning, which are caused by rapid changes in the culture of modern society. Particularly, significant factors influencing the situation in education are the following: the information field expansion, the rapid development of mass media having a powerful influence over the young generation, strengthening the individualistic features in the nature of young people, their social isolation, aesthetic disorientation, artistic inactivity. Under such circumstances, choral singing in educational institutions remains one of the few effective means of introducing children and teenagers to making music in teams that has the ability to offset the negative effect of the cultural factors mentioned below.

Obviously, the students' choral singing requires the involvement of a skilled organizer and teacher of this type of musical activity. As a rule, the role of organizer and leader is performed by a music teacher. Thus, he/she should have all the qualities needed to perform these functions.

This article is devoted to the problem of studying the ability of a music teacher to conduct the choral singing. The particular feature of our approach consists in finding out the qualities that a music teacher needs to possess in order to manage the chorus.

This issue has both theoretical and practical relevance that is of great importance. It particularly concerns modern China where qualified music teachers are still highly required. Teachers in China who do not possess the special chorus conducting training qualities can often perform the functions of music teachers. The problem of determining the degree of ability and skills of those music teachers and, particularly, the chorus conducting ones is still of current importance.

The aim of the article is to reveal a complex of qualities of a music teacher which are necessary and sufficient for an effective management of pupils' choral singing.

Major content. The complex of properties given is called in the article as an aptitude to chorus conducting. However, it must be mentioned that the word "ability" when used scientifically has two closely related but discernible semantic colours. The first is connected with the tradition of using the term "capacity" in a context of categories that characterize the sphere of individual and typological personality potencies. In this sense, this term is correlated with the concept of talent, skills, aptitude. According to the "classical" formulation by B. Teplov, "Abilities are usually considered to be individual characteristics that cannot be reduced to existent skills, abilities or knowledge, but which may explain 
the ease and swiftness of acquisition of knowledge and skills" [10, p. 16]. The second connotation of the word "ability" connects it with the concept of activity as well as with the concepts of aptitude and willingness of an individual to do some particular activity.

Having set the task of finding necessary and sufficient properties of chorus conducting activities in general, we do not have to pay attention to the countless options of combining the individual qualities of a person. We are precisely interested in qualities that must necessarily be peculiar to any chorus conductor. The training technique of music teachers at the university should be targeted at the same complex of qualities. This article deals with the word "ability" exactly in this meaning.

The word "aptitude" is widely used in Russian articles for specification of the second (active) semantic colour. Regarding this issue, S. Rubinstein wrote in his classic work, "Any ability is the ability to do something, to be able to do some activity. If a person has a certain ability, he/she may have the aptitude for a certain activity" $[9$, p. 535]. Thus, the terms "ability" and "aptitude" are not used here to define different psychological phenomena, but different points of view about this matter.

It needs to be considered which qualities exactly are required for a chorus conductor and in what way they ensure the effectiveness of his/her activities.

Many musicians and scientists have already given an answer to this question. Some of them have relied on their creative and pedagogical activity experience while others considered the theses of psychology, pedagogy, art.

For example, in the work of G. Dmitrevskiy [1], outlining the concept of chorus conducting as a discipline, a number of qualities that each chorus leader should possess was indicated. The following qualities were particularly mentioned by the author: familiarity with the basics of singing, singing skills, conscious attitude to verbal text, possession of the conductor's instrument, etc. Having such qualities makes it possible to perform three main functions that are peculiar to conductor's activity, i.e. the functions of a teacher, conductor and performer in particular. According to G. Dmitrevskiy, the main qualities of a chorus conductor are the following: a) the ability to attract the chorus's attention before performing, make it focused and concentrated, let the chorus "get tuned" [p. 42]; b) the ability to give a clear sign to the entry, "set the correct pace"; c) the ability to "show good entry and ending" [the same, p. 74-76]; g) "control and clear indication of dynamic shades", "audio feed" [the same, s.78-80]; d) the ability to "quickly analyze the audible, instantaneously react to the errors of chorus while performing" [the same, p. 68].

Interesting thoughts about the specialist's ability to conduct a chorus were expressed by K. Olkhov [7]. He compared a chorus conductor with a thinker, engineer, manager, controller, teacher, educator, and even with a "prophet, beacon and leading light at the same time". Not all such comparisons certainly identify personal characteristics required for activity of a chorus teacher.
K. Ptitsa expressed more specifically his thoughts about the qualities necessary for the chorus conductor in his article "Chorus conducting". The author sought to rely on the relevant psychological knowledge (probably he was influenced by Karl Schroeder). He proposed to distinguish between physiological aptitude and ability of a chorus conductor: "Conductor's natural gifts are composed of complex psychophysical features. These include not only the emotional and mental qualities, such as strong will, ability to response swiftly etc., but also purely physical ability. It is physical ability, physical mobility and agility that help the conductor in the learning process (or later performing process) to organize fast his/her, as it may appear at first, disconnected parts of the instrument into the most perfect, clear and active tools of performance managing" $[8, \mathrm{p} .7]$.

It is necessary to mention K. Ptitsa's use of the term "capacity" meaning "native physical capacity to perform the movements that are needed for the music timing. This physical aptitude of a musician is quite significant for chorus conducting because it is mainly based on the technical education of the conductor" [the same]. The term "physical aptitude" allows to define a set of natural gifts in a complex competent quality of a chorus conductor. However, this expression suggests the existence of both physical and also psychological prerequisites for the individual's ability to conduct a chorus.

K. Ptitsa defined common musical abilities (high-pitch hearing, sense of rhythm, etc.) and "deep musical culture" among the necessary psychological abilities. The main and specific ability of a chorus conductor is regarded by K. Ptitsa as "the capacity to conduct"; he defines this characteristic feature of a musician as "the possibility of revealing inner emotions through the expressive movements and the ability to influence the performers with it" [the same, p. 8-9]. It is quite interesting to mention, that the "managing ability", according to the researcher, "is felt even through the disturbing distortion of technical actions of the conductor's instrument" [the same].

While studying this issue, it is necessary to take into consideration not only the standpoints of the choral art masters, but also the opinions of symphonic and opera conductors (managing the musical team has its clearly expressed specific character, but also a lot of similarities with the art of chorus control). For example, the outstanding conductor Kirill Kondrashin when answering a question made by V. Razhnikov about the combination of skills and abilities necessary for a conductor, replied as follows: "It seems to me that a comprehensive system is required. Firstly, we need to mention the advanced music skills. I mean absolutely everything that other performers need, in addition to that even more keen harmonic hearing, developed dynamic hearing (i.e. the so-called sense of the sound balance), abilities to perform gestures, administrative talent. Moreover, willingness is seen as the most important criterion" $[4, \mathrm{p} .8]$.

There is absolutely no exaggeration in saying that in every reliable research or in any methodical work dedicated to the art of conducting, occur to some extent the wellknown ideas about the qualities that any chorus or orchestra 
conductor should possess, being summarized and presented in the categories such as "abilities", "willingness", "competence" and others. The article's frames, however, do not cover a wide range of opinions expressed. In other words, there is no necessity in that. Our task, as mentioned above, is not to conclude the complex of qualities, but to define those components of the conducting and choral competence of a music teacher, which are the key to manage the students' singing.

Taking into consideration well-known ideas of various researchers, teachers and chorus conductors, it is necessary to mention a number of the most commonly known and analyzed qualities of a music teacher that determine his/her ability to conduct a chorus. It includes the following:

1) a developed musical hearing and musical memory;

2) a strong, deep and detailed knowledge of music and poetic text of the composition performed;

3) possession of choral vocalization skills;

4) conductor's gesticulation skills;

5) organizational and volitional qualities of a personality.

In general, all of these qualities were studied thoroughly and in detail. However, upon close examination, it is possible to detect signs of incompleteness and uncertainty in the scientific understanding of the qualities mentioned above. Especially difficult may seem the thesis of volitional and organizational qualities of a chorus conductor.

Of course, the will itself is considered to be a prerequisite for a musician's ability to lead a music team. At the same time, will is a quality that is absolutely necessary in any field of activity. No work is possible without will. Then why all authors unanimously consider will as an attributive quality of a music team conductor?

It is believed that in such cases a special meaning of will is applied. It is not simply a question of a strong will. A strong will can be observed, for example, when some people show an exceptional ability to overcome their own fear of pain and death and endure the difficulties that an ordinary person may consider to be insuperable. Strong will can always be found in the psychological content of military or labour achievement. For an orchestra conductor, chorus conductor and music teacher who conducts singing, this kind of will is not such a necessary quality. What kind of specific feature does this will have?

K. Kondrashin explains the peculiarities of a conductor's will in the following way: "It is a certain kind of stubbornness. A conductor needs to be convinced in the correctness of his/her ideas and not be influenced by the sound the orchestra offers. He/she should definitely imagine beforehand while preparing at home what and in what way should sound, and make the orchestra respond to his ideas" [the same]. This statement connects a conductor's will with the stubbornness. This figurative comparison allows us to understand better the meaning of this phenomenon. But stubbornness is not always necessary for a music conductor (as well as for any specialist). "Stubbornness" may lead to positive consequences and could even be justified only when it complies with some certain requirements.
One of the requirements needed has been stated by $\mathrm{K}$. Kondrashin: "The willingness of a conductor should be directed at a certain sound result achievement, which, in its turn, is a product of a large inner perceptible and intellectual work on creation of a sound image of a composition".

This idea fully refers to the actions of a music teacher. His/her will to conduct a chorus should be aimed at the achievement of the sound image of a song or a choral piece, which was formed in the preliminary process of working on a specific artistic text. All other teacher's qualities that define his/her "ability" to chorus conducting, such as musical audition, memory, vocal skills, conductor's instrument etc., comply with this volitional need.

Thus, the will to control the sound presented is considered to be the central component in a complex of properties that determine the teacher's ability to chorus conducting.

Now it may seem necessary to specify the volitional conditions of a music teacher determined by the specific features of his/her profession.

Firstly, it is important to realize that in terms of aimtargeting, choral singing of pupils from school is significantly different from the one of professional choirs. The task of choral and orchestra conductors lies in creating the perfect sound form which can be adequate to author's intention. Exactly this sound form that is being created by a conductor and performers, must appeal to the audience and bring aesthetic pleasure. As for chorus students (especially when it comes to the most common situation like singing at music lessons), it is not intended to persuade, delight or to give "spiritual nourishment" to the audience. In this situation, choral students perform the role of listeners. So, in this case, it seems impossible not to consider the fact that choral students acquire themselves their own aesthetic and ethical satisfaction, reason for emotional reaction needed for the work of imagination, fantasy. It is logical to assume that the will of a chorus conductor should be aimed at this effect in the first place. Paraphrasing the words of K. Kondrashin, the following can be said: he who has no will like this is no music teacher.

A special attention needs to be paid to the detail that is often overlooked by researchers who study the volitional qualities of a chorus conductor. It is necessary to keep in mind that the purpose of choral singing (especially at music lessons) should not only be the acquisition of positive artistic and aesthetic experience from the sound perceived, but also to enjoy and derive benefits from the process of collective making of music. However, in the professional performing art such a goal is considered to be not a major one.

That is why a conductor of a professional chorus or orchestra does not have to worry whether the musicians like the piece performed or not or if it is necessary for their skills or their cultural development. A professional musician must possess his/her own will to act and the ability to obey the conductor's will that is aimed at a specific audio result.

A music teacher at school is something completely different. According to the terms of educational institutions that students should always obey the will of a teacher, this idea should not unconditionally be applied to situations of team 
activity. Playing music, as well as any other artistic or creative act, must not be something forced. Art itself assumes a personal freedom of expression (A. Bogdanov, G. Heine, G. Hegel, V. Hugo, F. Nietzsche, L. Tolstoy, A. Schopenhauer and others shared their thoughts on this matter). Submission to the will of a teacher who is guiding the process of team singing can only be a an act of will (assuming that the purpose of this activity is a true artistic education and training, and not a formal imitation of achieving this goal). Consequently, the attributive quality of a music teacher lies above all in uniting and directing all students to collective making of music, and only then in achieving specific sound effect.

Awareness of this condition may suggest the so-called phenomenon of synergy. This term has already gained the status of a universal category in modern scientific studies. It had already penetrated into the sphere of educational research (articles written by $\mathrm{N}$. Batechko, Yu. Vetrov, V. Grebneva, I. Kalinin, O. Kryukova, T. Matveychuk, A. Svidzinskiy,M. Fedorov and others). However, despite the availability of several dozens of articles on this problem, it is still impossible to talk about "synergetic" (or "synergistic") approach in pedagogy as a successful scientific project. At the same time, the willingness to understand the synergy principle in education is quite natural and, to all appearances, has every reason to become soon a major theoretical and practical approach. In any case, there is no doubt in the appropriateness of referring to the synergy category in the field of musical pedagogy. Productive efforts to understanding the art of music and musical performance have been undertaken by I. Yergiev (the scholar reflects on the spiritual cooperation of a performer and audience [2]) and Huang Jia (who examines the aspects of interaction between a singer and a conductor of the orchestra in chamber vocal performance [11]).

Synergy as a term (from the Greek "synergeia" meaning cooperation, community) in the most general sense is considered to be a "combined action of any component, in which the total effect outnumbers the action of each component taken separately" [3].

An attempt was made to understand the general meaning of the word "synergy" in choral singing. Based on this, one may find that this kind of music making involves several parameters of the joint efforts of all the participants (actants) of a sound-making process. Firstly, it is possible to state the presence of synergy of singers who are singing in a chorus. It is obvious that the sound of a chorus (effect in total) obviously "exceeds the individual effect" (a person singing alone). Synergetic interaction of performers is expressed, for

\section{ЛИТЕРАТУРА}

1. Дмитревский Г. А. Хороведение и управление хором / Г. А. Дмитревский. - М. : Музгиз, 1948.

2. Ергиев И. Исполнительская синергия как главный системообразующий элемент артистического универсума / И. Ергиев // Методологія, теорія і практика музичного виконавства. Науковий вісник НМАУ імені П. І. Чайковського. - К. : НМАУ, 2010. - Вип. 107. - C. 28-40. example, in a dynamic and timbre unison sound effect, as well as in the phenomenon of pitch system and the tempo metric ordering. Secondly, it seems necessary to mention the always desirable but not often achieved synergy between the chorus and the chorus conducting teacher. The teacher's conducting actions serve in this case as the main factor opposing the entropy of joint singing. Although, this factor seems not to be the only one.

A prerequisite for the synergy discussed is: a) the actual connection between choral members and the actions of a chorus conductor (chorus is dependent from the effectiveness of his/her gesticulation, facial expression, musical and intonational, as well as sound-verbal action); b) the chorus conductor's dependence on chorus singing (from the drill, metric, dynamic and articulating correctness of intonation).

The synergy plans that were previously characterized remain in correlation with each other. However, the nature of this correlation may be different. This issue requires a special consideration taking the following into account: a) the psychology of individual and team activity; b) intonation and sound effects created by the synergy of singing; c) the biophysical interaction between actants.

The analysis of synergetic relationships of a chorus and its conductor will allow to judge the nature of the will and the other components of personal qualities determining the professional ability of a music teacher more thoroughly and accurately. Firstly, such knowledge will allow to define the ability of a teacher to conduct a chorus and, secondly, prevent him/her from understanding his/her tasks and the means of handling them incorrectly, as well as particularly from the false idea about conductor's will and the forms of its manifestation in the musical and creative practice.

At this stage of the research, the following conclusions can be made:

1. The ability of a music teacher to control the chorus is a complex of qualities of his/her personality that are necessary and sufficient for positive and effective influence on his/her students.

2. The range of necessary qualities that any teacher should possess in order to conduct a chorus is the following: a) the development of musical hearing and musical memory; b) vocalization skills; c) conductor's gesticulation skills; d) volitional, artistic and organizational abilities.

3. The teacher's ability to achieve the synergy effect in the interaction between performers while making music is considered to be a specific component of his/her aptitude to choral conducting.

3. Комлев Н. Г. Словарь иностранных слов / Н. Г. Комлев. - М. : Эксмо-Пресс, 2000. - 1308 с.

4. Кондрашин К. Мир дирижера (технология вдохновения) / К. Кондрашин. - Л. : Музыка, 1976. $192 \mathrm{c}$.

5. Крюкова О. Синергетика и педагогика [Электронный ресурс] / Ольга Крюкова / Независимая академия эстетики и свободных искусств. Вып. 12. Тет- 
радь седьмая. Проблемы образования. - Режим доступа http://www.independentacademy.net/science/tetradi/12/kryukova.html.

6. Матвійчук Т. В. Педагогічні здібності викладача вищого навчального закладу з позицій інтегрального дослідження індивідуальності [Електронний pecypc] / Т. В. Матвійчук // Збірник наукових праць Хмельницького інституту соціальних технологій Університету «Україна». - 2009. - № 1. - С. 89-91. - Режим http://nbuv.gov.ua/UJRN/Znpkhist_2009_1_23. доступу:

7. Ольхов К. А. Вопросы теории дирижерской техники и обучения хоровых дирижеров / К. А. Ольхов. - Л. : Музыка, 1979. - 200 с.

\section{REFERENCES}

1. Dmitrevskiy, G. A. (1948). Khorovedenie $i$ upravlenie khorom [Choral studies and chorus conducting]. Moscow: Muzgiz [in Russian].

2. Yergiev, I. (2010). Ispolnitelskaya sinergiya kak glavnyy sistemoobrazuyuschiy element artisticheskogo universuma [Performing synergy as a major strategic element of artistic universum]. Metodolohiia, teoriia $i$ praktyka muzychnoho vykonavstva. Naukovyi visnyk NMAU imeni P. I. Chaikovskoho - Methodology, theory and practice of musical artistic performance. Bulletin of National Music Academy of Ukraine named after P. I. Chaikovskyi, 107, 28-40. Kyiv: NMAU [in Russian].

3. Komlev, N. G. (2000). Slovar inostrannykh slov [Dictionary of foreign words]. Moscow: Eksmo-Press [in Russian].

4. Kondrashin, K. (1976). Mir dirizhera (tekhnologiya vdokhnoveniya) [The world of a conductor (impression tecnnique)]. Leningrad: Muzyka [in Russian].

5. Kryukova, O. (n.d.). Sinergetika i pedagogika [Synergy and pedagogy]. Nezavisimaya akademiya estetiki $i$ svobodnykh iskusstv. Tetrad sedmaya. Problemy obrazovaniya - Independent academy of aesthetics and free arts. The seventh notebook. Problems of education, 12. Retrieved from: http://www.independentacademy.net/science/tetradi/12/kryukova.html [in Russian].

6. Matviichuk, T. V. (2009). Pedahohichni zdibnosti vykladacha vyshchoho navchalnoho zakladu z pozytsii inte-
8. Птица К. Б. О хоровом дирижировании / К. Б. Птица - М. : Профиздат, 1960.

9. Рубинштейн С. Л. Основы общей психологии / С. Л. Рубинштейн. - М., СПб. : Изд-во «Питер», 2013. -713 c.

10. Теплов Б. Способности и одаренность / Б. М. Теплов. Избранные труды. В 2-х томах. Т.1. - М. : Педагогика, 1985. - С. 15-41.

11. Хуан Цзя. Интонационная синергия партий голоса и фортепиано в камерной музыке / Хуан Цзя // Аркадія: культурологічний та мистецтвознавчий журнал. - №1 (42). - Одеса, 2015. - С. 107-111.

hralnoho doslidzhennia indyvidualnosti [Pedagogical abilities of a lecturer of a higher education institution in terms of integral study of a personality]. Zbirnyk naukovykh prats Khmelnytskoho instytutu sotsialnykh tekhnolohii Universytetu «Ukraina»-Collection of scientific papers of Khmelnitskyi institute of social technologies of "Ukraine" university, 1, 89-91. Retrieved from: http://nbuv.gov.ua/UJRN/Znpkhist_2009_1_23 [in Russian].

7. Olkhov, K. A. (1979). Voprosy teorii dirizherskoy tekhniki i obucheniya khorovykh dirizherov [Issues of theory of conductor's technique and teaching choral conductors]. Leningrad: Muzyka [in Russian].

8. Ptitsa, K. B. (1960). O khorovom dirizhirovanii [About choral conducting]. Moscow: Profizdat [in Russian].

9. Rubinshteyn, S. L. (2013). Osnovy obshchey psikhologii [Fundamentals of general psychology]. Moscow, St.Petersburg: Izdatelstvo «Piter» [in Russian].

10. Teplov, B. (1985). Sposobnosti i odarennost. Izbrannye trudy [Abilities and aptitudes. Selected works]. (Vols. 1). (pp. 15-41). Moscow: Pedagogika [in Russian].

11. Khuan, Tszya (2015). Intonatsionnaya sinergiya partiy golosa i fortepiano $\mathrm{v}$ kamernoy muzyke [Intonation synergy of vocal and piano roles in chamber music]. Arkadiia: kulturolohichnyi ta mystetstvoznavchyi zhurnal - Arcadia: journal of culture and fine arts studies, 1 (42), 107-111. Odesa [in Russian].

\section{Цао Хункай, \\ аспірант кафедри музичного мистецттва і хореографії, Південноукраӥнський національний педагогічний університет імені К. Д. Уиинського, вул Фонтанська дорога, 4, м. Одеса, Україна}

\section{ЗДАТНІСТЬ ДО КЕРУВАННЯ ХОРОМ ЯК КОМПОНЕНТ ПРОФЕСІЙНОЇ КОМПЕТЕНТНОСТІ ВЧИТЕЛЯ МУЗИКИ}

Статтю присвячено проблемі вивчення здатності вчителя музики до управління хоровим співом. Особливість нашого підходу полягає в тому, щоб з'ясувати, які властивості найбільшою мірою необхідні вчителю музики для здійснення завдання керівництва хором. Завдання статті полягає у виявленні комплексу властивостей вчителя музики, необхідних і достатніх для ефективного керівництва хоровим співом учнів. Здатність вчителя музики до управління хором - це комплекс тих якостей його особистості, які необхідні та достатні для позитивно результативного виконання завдань колективного музикування учнів. У комплекс обов'язкових властивостей здатності вчителя до управління хором входять: а) розвинений музичний слух і музична пам'ять; б) навик 
вокалізації; в) навик диригентської жестикуляції; г) вольові та художньо-організаційні здібності. Специфічним компонентом здатності до управління хором є здатність вчителя досягти ефекту синергії у взаємодії учасників процесу музикування. Стверджується, що найважливішим компонентом $є$ воля, спрямована на досягнення в процесі колективних дій певного звукового результату. Особливою якістю здібності вчителя музики до керівництва хором є вміння об'єднати та спрямувати волю всіх учнів на дію і результат спільного співу, тобто здатність вчителя досягти ефекту синергії у взаємодії всіх учасників процесу хорового співу. Така точка зору відкриває можливості для розвитку синергетичного підходу до вивчення феномена музичного навчання.

Ключові слова: вчитель музики, хоровий спів, керівництво хором, здатність, воля, синергія.

$$
\begin{array}{r}
\text { Цао Хункай, } \\
\text { аспирант кафедры музыкального искусства и хореографии, } \\
\text { Южноукраинский национальный педагогический университет имени К. Д. Ушинского, } \\
\text { ул. Фонтанская дорога, 4, г. Одесса, Украина }
\end{array}
$$

\section{СПОСОБНОСТЬ К УПРАВЛЕНИЮ ХОРОМ КАК КОМПОНЕНТ ПРОФЕССИОНАЛЬНОЙ КОМПЕТЕНТНОСТИ УЧИТЕЛЯ МУЗЫКИ}

Данная статья посвящена проблеме изучения способности учителя музыки к управлению хоровым пением. Особенность нашего подхода состоит в том, чтобы выяснить, какие свойства в наибольшей степени необходимы учителю музыки для осуществления задачи руководства хором. Задача статьи - выявление комплекса свойств учителя музыки, необходимых и достаточных для эффективного руководства хоровым пением учеников. Способность учителя музыки к управлению хором - это комплекс тех качеств его личности, которые необходимы и достаточны для позитивно результативного выполнения задач коллективного музицирования учеников. В комплекс обязательных свойств способности учителя к управлению хором входят: а) развитый музыкальный слух и музыкальная память; б) навык вокализации; в) навык дирижерской жестикуляции; г) волевые и художественно-организационные способности. Специфическим компонентом способности к управлению хором является способность учителя достичь эффекта синергии во взаимодействии участников процесса музицирования. Утверждается, что самым важным компонентом является воля, направленная на достижение в ходе коллективных действий определенного звукового результата. Особым качеством способности учителя музыки к руководству хором является умение объединить и направить волю всех учеников на действие и результат совместного пения, то есть способность учителя достичь эффекта синергии во взаимодействии всех участников процесса хорового пения. Такая точка зрения открывает возможности для развития синергетического подхода к изучению феномена музыкального обучения.

Ключевые слова: учитель музыки, хоровое пение, руководство хором, способность, воля, синергия.

Подано до редакиіï 21.04.2016

Рецензент: д. пед. н., проф. О. С. Реброва 